\title{
Phototherapy-Related Transient Direct Hyperbilirubinemia
}

\author{
Fototerapi Ilișkili Geçici Direkt Hiperbilirubinemi
}

\author{
Mehmet Kenan KANBUROĞLU1', Mehmet Nevzat ÇiZMECi², Ahmet Zülfikar AKELMA',

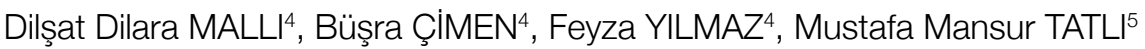

\begin{abstract}
${ }^{1}$ İstanbul Yeni Yüzyıl University, Özel Gaziosmanpaşa Hospital, Department of Pediatrics, Division of Neonatology, İstanbul, Turkey Bursa Yüksek İhtisas Training and Research Hospital, Department of Neonatology, Bursa, Turkey

${ }^{3}$ Keçiören Education and Research Hospital, Department of Child Health and Diseases, Ankara, Turkey

${ }^{4}$ Turgut Özal University, Faculty of Medicine, Department of Child Health and Diseases, Ankara, Turkey

${ }^{5}$ Izmir Katip Çelebi University, Faculty of Medicine, Department of Child Health and Diseases, Neonatology Department, Izmir, Turkey
\end{abstract}

\begin{abstract}
Objective: We aimed to investigate the frequency and possible risk factors of phototherapy-related direct hyperbilirubinemia.
\end{abstract}

Material and Methods: We scanned the medical records of 1301 patients who were admitted to the neonatology unit for indirect hyperbilirubinemia between 2005 and 2013. Infants with a clinical condition other than hyperbilirubinemia were excluded.

Results: Following phototherapy both the direct bilirubin level and direct bilirubin/total bilirubin ratio increased ( $p<0.001$ and $p<0.001$, respectively). The frequency of phototherapy-related direct hyperbilirubinemia was found to be $0.9 \%$ if the direct bilirubin/total bilirubin cut-off level was set to $20 \%$. The elevated direct bilirubin level and direct bilirubin/total bilirubin ratio returned to normal within three days, although they were still significantly higher than the pre-phototherapy levels $(p<0.001 ; p<0.001$, respectively). The increase in direct bilirubin level and direct bilirubin/total bilirubin ratio were found to be brisker in patients with ABO incompatibility ( $p<0.001$ and $p<0.001$, respectively).

Conclusion: The direct bilirubin level and direct bilirubin/total bilirubin ratio may temporarily rise following phototherapy. This deviation is short term, and ABO incompatibility is the only identified risk factor.To prevent unnecessary investigations this phenomenon should kept in mind by the physicians caring for infants.

Key Words: Adverse events, Hyperbilirubinemia, Newborn, Phototherapy

\section{ÖZET}

Amaç: Çalışmamızı fototerapi ilişkili direkt hiperbilirubineminin sıklı̆̆ını ve olası risk faktörlerini saptamak amacıyla planladık.

Gereç ve Yöntemler: Yenidoğan ünitesine indirekt hiperbilirubinemi tanısı ile 2005 ve 2013 yılları arasında yatan 1301 yenidoğanın dosyaları geriye dönük olarak tarandı. Hiperbilirubinemi haricinde başka hastalığı da olan yenidoğanlar çalışmadan çıkartıldı.

Bulgular: Fototerapiyi takiben hem direkt bilirubin seviyesi hem de direkt bilirubin/total bilirubin oranı artmaktadır (sırasıyla $p<0.001$ ve $p<0.001$ ). Patolojik direkt bilirubin/total bilirubin sınıı \%20 alındığında, fototerapi ile ilişkili direkt hiperbilirubinemi sıklı̆̆ı \%0.9 olarak bulundu. Artmış direkt bilirubin seviyeleri ve direkt bilirubin/total bilirubin oranı 3 gün içerisinde normale dönmekteydi, fakat bu değerler halen fototerapi öncesindeki değerlere göre anlamlı olarak yüksekti (sırasıyla $p<0.001$ ve $p<0.001$ ). ABO uygunsuzluğu olan hastalarda direkt bilirubindeki ve direkt bilirubin/total bilirubin değerindeki artışın daha hızı olduğu saptandı (sırasıyla $p<0.001$ ve $p<0.001$ ).

Sonuç: Fototerapi sonrasında direkt bilirubin düzeyi ve direkt bilirubin / total bilirubin oranı geçici olarak artabilmektedir. Bu durum kısa sürelidir ve saptanabilen tek risk faktörü ABO uygunsuzluğudur. Gereksiz ileri araştırmaların önüne geçilmesi açısından yenidoğanların tedavisinde görev alan doktorların bu durumu akılda tutmaları yararlı olacaktır.

Anahtar Sözcükler: Yan etki, Hiperbilirubinemi, Fototerapi, Yenidoğan

Correspondence Address / Yazışma Adresi:

Mehmet Kenan KANBUROĞLU

İstanbul Yeni Yüzyll University, Özel Gaziosmanpaşa Hospital,

Department of Pediatrics, Division of Neonatology, Istanbul, Turkey

E-mail: drkenankan@hotmail.com
Received / Geliş tarihi : : 21.03.2015 Accepted / Kabul tarihi : 06.08.2015

Online published : 01.04 .2016

Elektronik yayın tarihi

DOI: 10.12956/tjpd.2016.214 


\section{INTRODUCTION}

Phototherapy is the primary form of therapy for neonatal indirect hyperbilirubinemia (1). Although some minor side effects including ashes, loose green stools, water loss, oxidative injury, and dehydration were determined, no severe adverse reactions or long-term complications have been reported since this treatment was introduced into clinical practice in 1958 $(2,3)$. Nevertheless, it may still possess unknown risks (4-6). As previously reported in the literature, we frequently observed that the direct bilirubin (DB) levels of some infants were elevated following phototherapy (7). Unlike indirect hyperbilirubinemia, direct hyperbilirubinemia is never normal or physiological, and early diagnosis and treatment are essential to achieving a better outcome $(8,9)$. Therefore, it is important to differentiate phototherapy-related transient direct hyperbilirubinemia from direct hyperbilirubinemia due to other serious conditions. We retrospectively investigated our patients to determine in whom and to what extent phototherapy-related transient direct hyperbilirubinemia was observed.

\section{METHODS}

We scanned the medical records of 1301 patients who were admitted to the neonatology unit for indirect hyperbilirubinemia between October 2005 and February 2013. The digital database of our hospital was used. All infants were under the age of 15 days. Infants with a clinical condition other than indirect hyperbilirubinemia and/or a gestational age of $<37$ weeks were excluded from the study. Of the remaining 861 infants, 225 were subjected to the collection of blood samples to determine both the direct and total bilirubin (TB) levels before and just after the phototherapy. DB/TB>20\% was used as the diagnostic criteria to define direct hyperbilirubinemia (9-12). The frequency of and possible risk factors for phototherapy-related transient direct hyperbilirubinemia were investigated.

Phototherapy was given by light-emitting diodes (LEDs) and fluorescent lamps with a peak output of 420-540 nm and an irradiance $10-40 \mu \mathrm{W} / \mathrm{cm}^{2} / \mathrm{nm}$. Treatment decisions to start phototherapy were made according to the recommendations of the American Academy of Pediatrics $(1,11)$. The treatment duration varied from 12 to 48 hours according to the clinical status of the patients. The Diazo method was used to measure DB and TB on a Roche Cobas Integra 800 analyzer (Germany).

\section{Statistics}

The data are presented as the mean (95\% confidence interval) for continuous variables and as frequencies and percentage for categorical variables. Pearson's correlation coefficients were used to investigate the associations between variables. The paired sample T-test was used to compare repeated continuous variables before and after phototherapy. Repeated measures analysis of variance (rANOVA) was used to compare repeated measurements of the bilirubin fractions according to sex, ABO and $\mathrm{Rh}$ incompatibility and the type of delivery. Sphericity was assessed using Mauchly's Test, and the Greenhouse-Geisser or Huynh-Feldt correction was applied whenever needed to correct the degrees of freedom. The Sidak correction was used as a post hoc test for rANOVA when there were more than two groups. A p value $<0.05$ was considered significant for twotailed tests. Descriptive analysis of the data and analysis of variance were performed with SPSS 17.0 for Windows (SPSS, Chicago, IL). Before subject enrollment, the study protocol was reviewed and approved by the Hospital's Local Human Subjects Research Ethical Review Board.

\section{RESULTS}

The baseline characteristics and bilirubin fractions of the 225 infants are given in Table I, II. All patients were treated with phototherapy, and in no case was an exchange transfusion necessary. DB and DB/TB ratio were both elevated following phototherapy (Figure 1).

The frequency of phototherapy-related transient direct hyperbilirubinemia was found to be $0.9 \%$ (Table II). Although the DB levels of patients measured one to three days after phototherapy were higher than the pre-treatment values, none of the patients remained within the range indicative of direct hyperbilirubinemia.

The gestational age and the $\mathrm{DB}$ and $\mathrm{DB} / \mathrm{TB}$ ratio at the time of admission were found to be correlated with the DB and DB/TB values following phototherapy (Table III).

The DB and DB/TB levels of infants who had ABO incompatibility increased faster than the levels of the rest of the patients; moreover, their levels returned to normal more quickly than the levels of the others (Figure 2, rANOVA $p<0.001$ and $p<0.001$, respectively). However, at the end of three days there was no difference. The magnitudes of the increases in $\mathrm{DB}$ and $\mathrm{DB} / \mathrm{TB}$ were not different according to $\mathrm{Rh}$ incompatibility, the use of intravenous immunoglobulin, sex, birth weight or gestational age of the patients.

\section{DISCUSSION}

Current management protocols for neonatal hyperbilirubinemia in infants do not recommend the routine measurement of the DB level unless the infant is more than two weeks old. It is argued that DB measurements offer little, if any, assistance in evaluating patients with neonatal hyperbilirubinemia $(7,13)$. Publications that reported low diagnostic importance of elevated DB suggest measuring only total bilirubin in patients with neonatal hyperbilirubinemia $(7,13)$. Contrary to the suggestions, Mamtani et al.(14) reported that the measurement of the DB 
bilirubin level can independently and additively improve the prognostication for infants with neonatal hyperbilirubinemia, especially in developing countries.

Newman et al. conducted one of the studies that recommended using only the TB levels in neonatal hyperbilirubinemia (7). In that study, 2877 infants were retrospectively investigated, and $5 \%$ of them were found to be in the range corresponding to direct hyperbilirubinemia. Most of these infants' DB levels returned to normal, and it was concluded that DB measurement is not reliable and is unnecessary in infants before they reach two weeks old. The increase in DB was mostly unexplained or attributed to false positivity of the test method used (the Jendrassik-Grof reaction). However, they also detected conjugated hyperbilirubinemia in 9 out of the 235 (4\%) infants who were tested by the Ektachem method which provides a good estimate of the conjugated bilirubin levels (15).

Although the amount of direct bilirubin depends on the concentration of conjugated bilirubin, these two quantities are not the same. The accuracy of the measured concentration of DB depends on the method used. We used the diazo method in our study and it is one of the most widely used methods for measuring bilirubin levels. For methodological reasons, higher total bilirubin levels (even if it is all unconjugated) result in higher measured DB bilirubin levels with the diazo method (16). The absence of elevated DB levels in the pre-phototherapy group despite the higher TB levels following phototherapy suggests that the elevated levels were not associated with the method

Table I: Baseline characteristics of the patients.

\begin{tabular}{l|l|l}
\hline Gestational age & $38.9 \pm 1.3$ weeks & \\
Birth Weight & $3279 \pm 392$ grams & \\
Gender (\%) & Male: 53.4 & Female: 46.6 \\
Delivery (\%) & Vaginal: 46.6 & Caesarean: 53.4 \\
\hline
\end{tabular}

Numbers are given as mean $\pm S D$.

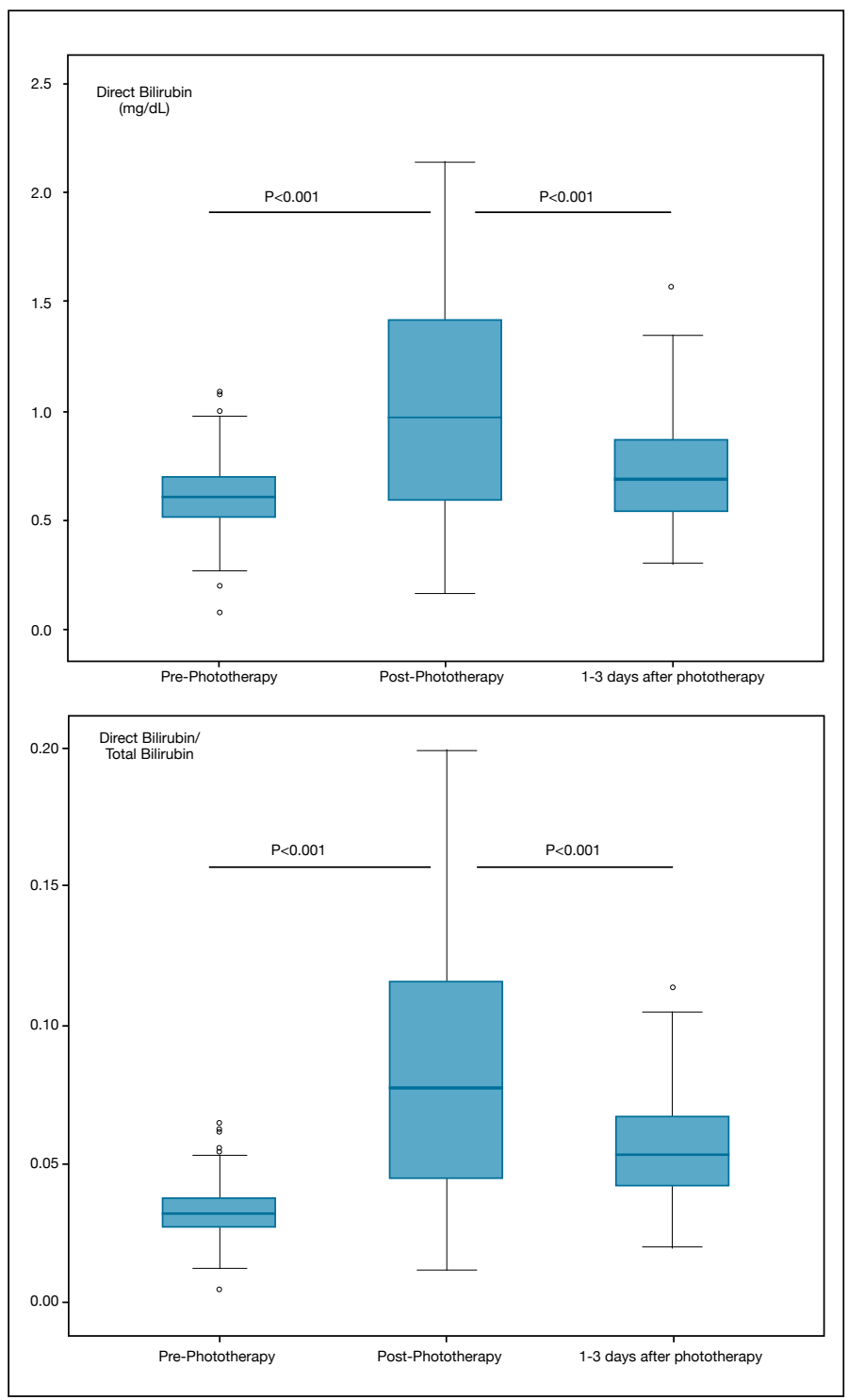

Figure 1: DB, DB/TB levels according to the effect of phototherapy. DB:direct bilirubin, TB:total bilirubin.

Table II: Bilirubin fractions in respect to phototherapy timing.

\begin{tabular}{|c|c|c|c|}
\hline & Pre-phototherapy & Post-phototherapy & 1-3 days after phototherapy \\
\hline TB (mg/dl) & $18.5(18.1-19.0)$ & $12.8(12.5-13.1)$ & $12.9(12.6-13.2)$ \\
\hline DB (mg/dl) & $0.62(0.59-0.64)$ & $1.01(0.95-1.11)$ & $0.72(0.68-0.75)$ \\
\hline $\mathrm{DB} / \mathrm{TB}>\% 20(9-12)$ & 0 & $2(0.9 \%)$ & 0 \\
\hline
\end{tabular}

Numbers are given as mean (95\% confidence interval) or percentage. DB: Direct bilirubin, TB: Total bilirubin.

Table III: Correlations of phototherapy-related transient direct hyperbilirubinemia.

\begin{tabular}{|c|c|c|c|c|c|c|}
\hline \multirow[b]{2}{*}{$D_{f p}$} & \multicolumn{2}{|c|}{ Gestational Age } & \multicolumn{2}{|c|}{$D_{b p}$} & \multicolumn{2}{|c|}{$\mathrm{DB} / \mathrm{TB}_{\mathrm{bp}}$} \\
\hline & $r:-0.17$ & p: 0.013 & $r: 0.30$ & $p<0.001$ & r: 0.22 & p: 0.001 \\
\hline $\mathrm{DB} / \mathrm{TB}_{\mathrm{fp}}$ & $r:-0.19$ & p: 0.005 & $r: 0.30$ & $p<0.001$ & r: 0.26 & $p<0.001$ \\
\hline
\end{tabular}

$\mathbf{D B}_{f p}$ : Direct bilirubin level following phototherapy, $\mathbf{D B} / \mathbf{T B}_{\boldsymbol{f b}}$ : Ratio of direct bilirubin to total bilirubin following phototherapy, $\boldsymbol{D B}_{b \boldsymbol{p}}$ : Direct bilirubin level before phototherapy, $\mathbf{D B} / \mathbf{T B}_{\boldsymbol{f b}}$ : Ratio of direct bilirubin to total bilirubin before phototherapy, $\boldsymbol{r}$ : Pearson correlation. 

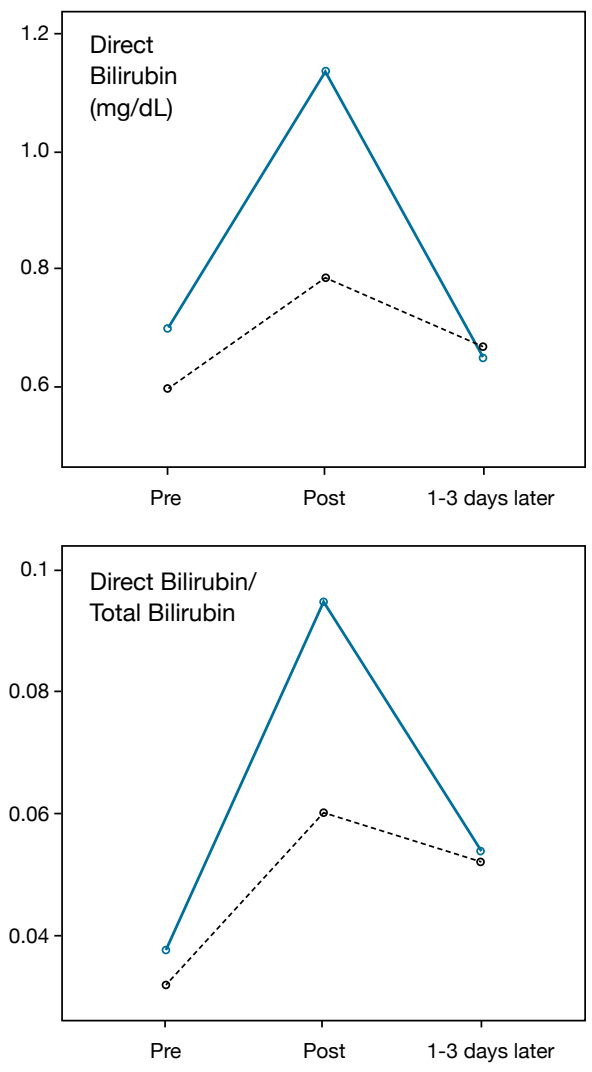

Figure 2: Change in the means of $\mathrm{DB}$ and $\mathrm{DB} / \mathrm{TB}$ of patients with and without $\mathrm{ABO}$ incompatibility. $\mathrm{ABO}$ incompatibility, ---: the rest of the patients, DB: direct bilirubin, TB: total bilirubin, Pre: before phototherapy, Post: just after phototherapy.

used. However, the diazo method does measure bilirubin conjugates together with delta-bilirubin (17). Delta-bilirubin accounts for less than $2 \%$ of the total bilirubin in infants younger than 28 days; therefore, the detected phototherapy-related transient direct hyperbilirubinemia may be due to an increase in bilirubin conjugates or delta-bilirubin, or both (18).

Phototherapy devices other than LED may cause loss of fluid and were included in the possible explanation of bile sludge previously (19). Inspissated bile syndrome may be associated with dehydration, total parenteral nutrition and massive hemolysis (20). However, as far as we know, no ensuing study has been reported subjecting phototherapy and the inspissated bile syndrome. Conversely, babies have a better supervision on their oral intake at the hospital and are thus not prone to weight loss. In the bile, the mean concentrations of (ZZ)-bilirubin and (EZ)-cyclobilirubin increased nearly three- and ten-fold respectively, during phototherapy (21). The exact effect of these photoisomers on the bile content is not known.

Another possible explanation for the observed phototherapyrelated transient direct hyperbilirubinemia is the impact of light on DB measurements. When infants' serum was irradiated with light in vitro, false increases in the DB values were detected by the bilirubin oxidase method. However, the DB concentrations after photoirradiation remained unchanged when measured by the diazo method (22). Photoisomers of bilirubin produced during phototherapy may also react directly. Nevertheless, not much is known about this possibility (23).

In the early period after the onset of direct hyperbilirubinemia in neonates with conditions such as idiopathic neonatal hepatitis or biliary atresia, the direct reacting portion may account for only $10-20 \%$ of TB, and the onset of acholic stools is frequently delayed until 2 weeks of life or later. As hepatic conjugation and the uptake of bilirubin mature, IB decreases while DB increases (24-26). Therefore, a proportion of DB greater than 10\% should always alert the physician. Being aware of the transient nature of phototherapy-related transient direct hyperbilirubinemia may prevent unnecessary investigations in patients incidentally found to have high levels of DB during phototherapy.

The increase in the DB levels following phototherapy seems to be reversible, and the elevated DB levels were seldom in the diagnostic zone; however, direct hyperbilirubinemia should never be considered normal or physiological. Thus, unless other studies also demonstrate a definite relationship between phototherapy and direct hyperbilirubinemia, patients in this situation should be followed up with skepticism. It is best to use the recommendations of the North American Society for Pediatric Gastroenterology, Hepatology, and Nutrition (cut off value of $\mathrm{DB} / \mathrm{TB}>\% 20$ ) to reduce the rate of phototherapyrelated transient direct hyperbilirubinemia (9). The historically mentioned methods of DB $>2.0 \mathrm{mg} / \mathrm{dL}, \mathrm{DB}>1.5-2.0 \mathrm{mg} / \mathrm{dL}$ and/or DB/TB > $10-20 \%$ should not be used; as the incidence of phototherapy-related direct hyperbilirubinemia would be as high as $\% 4$ and $36 \%$ respectively with these cut off values in our study $(27,28)$.

It is also an unexpected finding that patients with $\mathrm{ABO}$ incompatibility had higher direct bilirubin levels during phototherapy. We could not find an explanation for this observation.

Although a significant increase in DB was observed in our patients receiving phototherapy, we do not recommend the routine measurement of DB during or after phototherapy. Both $\mathrm{DB}$ and the $\mathrm{DB} / \mathrm{TB}$ ratio of the patients returned to normal at the end of 3 days, and there is no evidence that these transient increases have long-term side effects. Furthermore, elevated levels of DB during first two weeks of life have very low sensitivity and specificity for the management of neonatal hyperbilirubinemia $(7,13)$.

In conclusion, the $\mathrm{DB}$ level and $\mathrm{DB} / \mathrm{TB}$ ratio increase following phototherapy. The frequency of phototherapy-related direct hyperbilirubinemia was found to be $0.9 \%$ if the DB/TB cut-off level was set to $20 \%$. The only identified risk factor was $A B O$ incompatibility. Although it seems to be temporary, physicians caring for infants should be aware of this condition. 


\section{REFERENCES}

1. Bhutani VK, Committee on Fetus and Newborn; American Academy of Pediatrics. Phototherapy to prevent severe neonatal hyperbilirubinemia in the newborn infant 35 or more weeks of gestation. Pediatrics 2011;128:e1046-52.

2. Vreman HJ, Wong RJ, Stevenson DK. Phototherapy: Current methods and future directions. Semin Perinatol 2004;28:326-33.

3. Scheidt PC, Bryla DA, Nelson KB, Hirtz DG, Hoffman HJ. Phototherapy for neonatal hyperbilirubinemia: Six-year follow-up of the National Institute of Child Health and Human Development clinical trial. Pediatrics 1990;85:455-63.

4. Tatli MM, Minnet C, Kocyigit A, Karadag A. Phototherapy increases DNA damage in lymphocytes of hyperbilirubinemic neonates. Mutat Res 2008;654:93-5.

5. Cohen AN, Ostrow JD. New concepts in phototherapy: Photoisomerization of bilirubin IX alpha and potential toxic effects of light. Pediatrics 1980;65:740-50.

6. Cetinkursun S, Demirbag S, Cincik M, Baykal B, Gunal A. Effects of phototherapy on newborn rat testicles. Arch Androl 2006;52: 61-70.

7. Newman TB, Hope S, Stevenson DK. Direct bilirubin measurements in jaundiced term newborns. A reevaluation. Am J Dis Child 1991; 145:1305-9.

8. Feldman AG, Sokol RJ. Neonatal cholestasis. NeoReviews 2013;14

9. Moyer V, Freese DK, Whitington PF, Olson AD, Brewer F, Colletti $\mathrm{RB}$, et al. Guideline for the evaluation of cholestatic jaundice in infants: Recommendations of the North American Society for Pediatric Gastroenterology, Hepatology and Nutrition. J Pediatr Gastroenterol Nutr 2004;39:115-28.

10. Sokol RJ, Shepherd RW, Superina R, Bezerra JA, Robuck $\mathrm{P}$, Hoofnagle $\mathrm{JH}$. Screening and outcomes in biliary atresia: Summary of a National Institutes of Health Workshop. Hepatology 2007;46:566-81.

11. American Academy of Pediatrics Subcommittee on Hyperbilirubinemia. Management of hyperbilirubinemia in the newborn infant 35 or more weeks of gestation. Pediatrics 2004;114:297-316.

12. Cherry Uy. Conjugated Hyperbilirubinemia. In: Gomella TL (ed). Neonatology; Management, Procedures, On-Call Problems, Diseases, and Drugs. 7th ed. United States of America: McGrawHill Companies; 2013:392-400.
13. Rosenthal P. Direct bilirubin measurements in term newborns-a waste of time and money? J Pediatr Gastroenterol Nutr 1992;15:220-1.

14. Mamtani M, Patel A, Renge R, Kulkarni H. Prognostic value of direct bilirubin in neonatal hyperbilirubinemia. Indian $\mathrm{J}$ Pediatr 2007;74:819-22.

15. Chan KM, Scott MG, Wu TW, Clouse RE, Calvin DR, Koenig J, et al. Inaccurate values for direct bilirubin with some commonly used direct bilirubin procedures. Clin Chem 1985;31:1560-3.

16. Heirwegh KP, Fevery J, Meuwissen JA, De Groote J, Compernolle $\mathrm{F}$, Desmet $\mathrm{V}$, et al. Recent advances in the separation and analysis of diazo-positive bile pigments. Methods Biochem Anal 1974;22:205-50.

17. Wu TW. Bilirubin analysis-the state of the art and future prospects. Clin Biochem 1984;17:221-9.

18. Brett EM, Hicks JM, Powers DM, Rand RN. Delta bilirubin in serum of pediatric patients: Correlations with age and disease. Clin Chem 1984;30:1561-4.

19. Gubernick JA, Rosenberg HK, llaslan H, Kessler A. US approach to jaundice in infants and children. Radiographics 2000;20:173-95.

20. Pfeiffer WR, Robinson LH, Balsara VJ. Sonographic features of bile plug syndrome. J Ultrasound Med 1986;5:161-3.

21. Onishi S, Isobe K, Itoh S, Manabe M, Sasaki K, Fukuzaki R, et al. Metabolism of bilirubin and its photoisomers in newborn infants during phototherapy. J Biochem 1986;100:789-95.

22. Ihara $H$, Aoki $Y$, Aoki T, Yoshida M. Light has a greater effect on direct bilirubin measured by the bilirubin oxidase method than by the diazo method. Clin Chem 1990;36:895-7.

23. Ruud Hansen TW. Phototherapy for neonatal jaundice--therapeutic effects on more than one level? Semin Perinatol 2010;34:231-4.

24. Phillips MJ, Poucell S, Oda M. Mechanisms of cholestasis. Lab Invest 1986;54:593-608.

25. Crawford JM, Hauser SC, Gollan JL. Formation, hepatic metabolism, and transport of bile pigments: A status report. Semin Liver Dis 1988;8:105-18.

26. Hofmann AF. Current concepts of biliary secretion. Dig Dis Sci 1989;34:16S-20S

27. Harb R, Thomas DW. Conjugated hyperbilirubinemia: Screening and treatment in older infants and children. Pediatr Rev 2007;28:8391.

28. Cherry Uy. Conjugated Hyperbilirubinemia. In: Gomella TL (ed). Neonatology; Management, Procedures, On-Call Problems, Diseases, and Drugs. 6th ed. United States of America: McGrawHill Companies; 2009:288-93. 